\title{
PENGEMBANGAN MODEL PEMBINAAN DISIPLIN PESERTA DIDIK DALAM MEMBANGUN KARAKTER BANGSA BERBASIS KELAS DI SMA NEGERI SUMATERA BARAT
}

\author{
Fitria Kasih, Helma \\ Program Studi Bimbingan Konseling STKIP PGRI Sumatera Barat \\ Korespondensi: Jln. Gunung Pangilun, Padang, Sumatera Barat \\ e-mail: kasih.fitria@yahoo.com
}

\begin{abstract}
The aims of the first year research were to figure out 1) forms and level of students' discipline, 2) factors influencing students' discipline, 3) forms of discipline encouragement carried out by the teachers. The result of the research will be used as a foundation for developing a model for students' discipline management in order to build classroom-based nation character in West Sumatera senior high schools in the second year. The first research method employed in the first year was descriptive analysis while in the second one was applied research and mixing research method. To collect the data, questionnaire was administered to the students and in-depth interview was for the teachers. The population was students from three regencies and municipalities: Kabupaten Agam, Kota Payakumbuh and Kabupaten Tanah Datar where two school from each of the regions were chosen randomly. Sampling techniques employed was area purposive sampling. The data for the first year was analyzed by means of percentage formula while for the second year was t-test. The ending product of the research was a model. The findings of the research showed that forms and level of students discipline were good. Next, factors influencing students' discipline were various. Last, forms of discipline encouragement carried out by the teachers were quite good. It was recommended from the first year research that a model for students' discipline management in order to build classroombased nation character in West Sumatera senior high schools was really needed.
\end{abstract}

Kata kunci: pembinaan, disiplin, karakter bangsa, kelas

\section{PENDAHULUAN}

$\mathrm{D}$ isiplin sekolah merupakan masalah yang mendapat perhatian dari semua pihak, bahkan sering masyarakat menjadikannya sebagai tolak ukur untuk menilai keberhasilan peserta didik. Hasil penelitian Darmansyah (Jurnal Pendidikan Skolar, 2001: 143) menemukan bahwa disiplin belajar peserta didik memiliki hubungan yang positif dengan hasil belajarnya. Sementara Thantawy R (Jurnal Bimbingan dan
Konseling, 2003: 54) menemukan bahwa faktor nonintelektual yang dominan dalam pencapaian prestasi belajar adalah disiplin dalam melakukan kegiatan belajar.

Untuk terbentuknya perilaku disiplin di kalangan peserta didik diperlukan adanya upaya pembinaan terutama yang dilakukan guru dalam kelas seperti menciptakan disiplin kelas. Oemar Hamalik (1998: 214) mengemukakan bahwa; kelas yang penuh disiplin akan 
memungkinkan peserta didik belajar dengan efektif serta turut mendorong motivasi belajarnya. Di sekolah, disiplin banyak digunakan untuk mengontrol tingkah laku peserta didik yang dikehendaki agar tugas-tugas atau kegiatan sekolah dapat berjalan dengan optimal (Ahmad Rohani 1995: 126). Kenyataannya, di beberapa sekolah disiplin belum dapat menjadi alat pengontrol perilaku peserta didik.

Masalah disiplin baik di sekolah maupun di luar sekolah bukan hanya merupakan suatu problem sosial yang menarik akan tetapi merupakan masalah pedagogis yang makin serius dan cukup meresahkan masyarakat baik di Sumatera Barat maupun di kota-kota besar lainnya. Banyak permasalahan yang terkait dengan karakter bangsa yang kalau kita cermati semua itu berakar pada persoalan disiplin, entah itu disiplin diri ataupun disiplin terhadap aturan. Ambil saja contoh kasus "Kebocoran Ujian Nasional". Kalau peserta didik dan guru di kelas masing-masing memiliki disiplin diri dan disiplin terhadap aturan tidak akan terjadi hal yang demikian. Berkaitan dengan ini dirasa perlu peningkatan kedisiplinan peserta didik melalui pembinaan dengan berbasis kelas, sekolah serta komunitas (Doni Koesoema, 2007: 233 ).

Berhubung disiplin adalah persoalan pedagogis maka pembinaan yang dilakukanpun harus bersifat pedagogis dengan menggunakan pendekatan yang edukatif. Seperti yang diungkapkan Winarno Surachmad (Prayitno, 2009: 2) bahwa praksis pendidikan harus berlandaskan ilmu pendidikan yang disingkat dengan PENTIP (Pendidikan dengan Ilmu Pendidikan), jika pendidik tidak menggunakan ilmu pendidikan maka akan terjadi kecelakaan dalam pendidikan (KEDIP). Sehubungan dengan hal ini muncul pertanyaan apakah pembinaan disiplin peserta didik yang dilakukan guru di kelas selama ini sudah berlandaskan ilmu pendidikan?
Selanjutnya bagi guru, permasalahan disiplin ini merupakan suatu tantangan dalam penanaman nilai-nilai berbasis kelas, sebab kelas merupakan tempat yang strategis dalam menanamkan nilai-nilai, termasuk nilai-nilai disiplin. Jadi kelas benar-benar menjadi sebuah wahana bagi praksis nilai dan moral. Praksis nilai dan moral inilah yang menjadi acuan keberhasilan pendidikan khususnya nilai-nilai disiplin baik di sekolah dan di luar sekolah. Sebab pendidikan nilai hanya bisa dilihat dari segi perilaku dan praksis bukan dari pemahaman teoritis. Sehubungan dengan hal di atas timbul pertanyaan apakah kelas sudah difungsikan sebagai tempat yang strategis dalam pembinaan disiplin peserta didik untuk membangun karakter bangsa yang kuat?

Sebenarnya kelas bukan merupakan tempat pentransferan ilmu yang sifatnya kognitif dan psikomotor saja, akan tetapi juga merupakan momen pendidikan karakter yang stategis. Di dalam kelas, guru tak ubahnya seorang manager yang sedang mengendalikan dan mengarahkan lingkungannya, dimana dalam pertemuan guru dan peserta didik inilah terdapat proses penanaman nilai dan moral secara lebih kongkrit. Dalam pendidikan karakter, di kelas setiap guru dituntut memiliki cara-cara bertindak yang edukatif, yaitu sebagai berikut:

1. Bertindak sebagai pengasuh, teladan dan pembimbing.

2. Menciptakan sebuah komunitas moral

3. Menegakkan disiplin di kelas

4. Menciptakan disipin kelas yang demokratis.

5. Mengajarkan nilai-nilai dan kurikulum dengan cara menggali isi materi pelajaran yang sangat kaya dengaan nilai-nilai dalam membangun karakter bangsa.

6. Mempergunakan metode pembelajaran melalui kerjasama agar 
peserta didik semakin mampu mengembangkan kemampuan mereka dalam memberikan aspirasi atas pendapat orang lain, berani berpendapat dan mau bekerjasama dengan orang lain demi berhasilnya tujuan bersama.

7. Membaangun sebuah rasa tanggung jawab bagi pembentukan diri.

8. Mengajak peserta didik berani memikirkan dan membahas persoalan yang berkaitan dengan konflik nilai.

9. Melatih peserta didik untuk belajar memecahkan konflik yang muncul secara adil dan damai tanpa kekerasan (Doni Koesoema 2007: 231-233).

Kenyataan di lapangan, belum semua hal di atas dilaksanakan guru secara edukatif sebagaimana yang ditemukan Arni Muhammad (Jurnal Forum Pendidikan, 1999: 26) bahwa pemberian contoh perilaku guru yang demokratis dalam mengelola kelas sehari-hari dapat meningkatkan iklim kelas menjadi lebih demokratis. Selanjutnya juga dikemukakan bahwa untuk merubah iklim kelas menjadi lebih demokraatis, terlebih dahulu guru hendaklah mempunyai kesadaran dan kemauan kuat untuk berubah dan menampilkan perilaku demokratis secara wajar dan alamiah. Hasil penelitiannya juga merekomendasikan bahwa perlu penelitian lanjutan dalam bentuk model perbaikan iklim kelas. Hal ini menuntut perlunya studi empiris lanjutan mengingat kelas adalah tempat yang strategis sebagai wadah pembinaan disiplin dalam membangun karakter bangsa.

Selain itu menurut Elfindri dkk (2010: 6) guru di kelas tidak hanya memberikan pengetahuan (kognitif) dan keterampilan (psikomotor) atau dalam bentuk hard skill yang hanya akan mengisi otak kiri peserta didik saja akan tetapi guru juga perlu mengajarkan kepada peserta didik keterampilan yang berupa soft skill, sehingga terjadi keseimbangan otak kiri dan atak kanan peserta didik. Salah satu bentuk dari soft skill yang perlu diajarkan adalah tentang disiplin. Selanjutnya dikatakan bahwa setiap guru bidang studi harus mengajarkan soft skill pada peserta didiknya, karena keberhasilan seseorang tidak hanya ditentukan dari dimilikinya pengetahuan (kognitif) dan keterampilan (psikomotor) saja akan tetapi lebih banyak ditentukan oleh soft skill yang dimilikinya. Ini berarti guru perlu membina disiplin peserta didik dalam menciptakan anak bangsa yang berkarakter kuat dan cerdas di kelas maupun di sekolah dimana mereka mengajar.

Melihat paparan di atas peneliti ingin melakukan studi empiris dengan rumusan masalah adalah: Bagaimana model pembinaan disiplin peserta didik dalam membangun karakter bangsa berbasis kelas di SMA Negeri Sumatera Barat. Yang pada akhirnya akan melahirkan suatu model pembinaan disiplin dalam membangun karakter bangsa yang efektif untuk dikembangkan oleh para guru SMA Negeri Sumatera Barat.

\section{TUJUAN DAN MANFAAT PENE- LITIAN}

\section{Tujuan Penelitian}

Secara umum penelitian ini bertujuan untuk menemukan model pembinaan disiplin di sekolah dalam membangun karakter bangsa berbasis kelas di SMA Negeri Sumatera Barat, sehingga mampu meningkatkan disiplin diri dan ketaatan terhadap peraturan baik di sekolah maupun di luar sekolah dalam membangun karakter bangsa yang baik di era golobal ini. Tujuan ini dapat dicapai dengan melakukan 2 tahap penelitian selama 2 tahun melalui pen- 
capaian tujuan khusus yang dirumuskan untuk masing-masing tahap tersebut.

Adapun tujuan khusus dari penelitian ini adalah sebagai berikut:

Untuk Tahun Pertama.

1. Mengetahui bentuk dan tingkat kedisiplinan peserta didik baik di sekolah maupun di luar sekolah pada SMA Negeri Sumatera Barat.

2. Mengetahui faktor-faktor yang mempengaruhi kedisiplinan peserta didik baik di sekolah maupun di luar sekolah pada SMA Negeri Sumatera Barat.

3. Mengetahui upaya pembinaan disiplin yang dilakukan para guru dalam membangun karakter bangsa berbasis kelas di SMA Negeri Sumatera Barat.

\section{Untuk Tahun Kedua}

1. Mengembangkan model pembinaan disiplin peserta didik di dalam dan luar sekolah dalam membangun karakter bangsa berbasis kelas di SMA Negeri Sumatera Barat.

2. Menguji coba keefektifan model pembinaan disiplin peserta didik di sekolah dan di luar sekolah dalam membangun karakter bangsa berbasis kelas di SMA Negeri Sumatera Barat.

3. Melahirkan model pengembangan disiplin peserta didik dalam membangun karakter bangsa berbasis kelas yang sudah baku dalam bentuk manual yang bisa dilaksanakan oleh para guru SMA Negeri di Sumatera Barat.

\section{Manfaat Penelitian}

Penelitiaan ini perlu dilakukan mengingat betapa besar manfaatnya bagi berbagai pihak seperti:

1. Bagi pihak pemerintah khususnya Dinas Pendidikan, kegiatan ini dapat membantu pihak Pemerintah Daerah Sumatera Barat khususnya
Dinas Pendidikan Kabupaten/ Kota dalam meningkatkan kualitas lulusan SMA Negeri yang tidak hanya memiliki pengetahuan dan keterampilan tetapi juga memiliki kepribadian sebagai anak bangsa yang memiliki karakter bangsa yang baik di era global ini.

2. Bagi guru, kegiatan ini dapat menambah wawasan, pengetahuan, keterampilan, nilai dan sikap (WPKNS) dalam melakukan pembinaan disiplin kepada peserta didiknya.

3. Bagi masyarakat, kegiatan ini membantu masyarakat dalam membina disiplin anaknya. Karena pembinaan disiplin di kelas akan berdampak terhadap disiplin anak di rumah dan di masyarakat.

4. Bagi peserta didik, kegiatan ini membantu mereka dalam menciptakan disiplin diri dan disiplin terhadap aturan baik di sekolah maupun di luar sekolah sehingga mereka memiliki karakter bangsa yang baik.

\section{METODOLOGI PENELITIAN}

Jenis penelitian pada tahun pertaama ini bersifat deskriptif analitis dan tahun keduanya adalah applied research. Metode yang digunakan dalam penelitian ini adalah mixing research. Populasi dan sampelnya peserta didik pada 3 Kabupaten/Kota yaitu: Kabupaten Agam, Kota Payakumbuh dan Kabupaten Tanah Datar yang masing-masingnya dipilih 2 buah sekolah untuk mewakili kabupaten/Kota tersebut. Teknik pengambilan sampelnya adalah Area purposive random sampling. Untuk lebih jelasnya pupulasi daan sampel dalam penelitian ini dapat dilihat pada tabel di bawah ini: 
Tabel 1: Sampel Penelitian Sekolah Menengah Atas Negeri Kabupaten/Kota di Sumatera Barat

\begin{tabular}{|c|c|c|c|c|c|}
\hline No & $\begin{array}{c}\text { Kabupaten / } \\
\text { Kota }\end{array}$ & $\begin{array}{l}\text { Jumlah } \\
\text { Sekolah }\end{array}$ & $\begin{array}{l}\text { Jumlah } \\
\text { Sampel }\end{array}$ & Sekolah & $\begin{array}{l}\text { Jumlah } \\
\text { Pesdik }\end{array}$ \\
\hline 1 & Kota Payakumbuh & 4 & 2 & $\begin{array}{l}\text { 1. SMA } 1 \text { Payakumbuh. } \\
\text { 2. SMA N } 3 \text { Payakumbuh }\end{array}$ & 115 \\
\hline 2 & Kabupaten Agam & 20 & 2 & $\begin{array}{l}\text { 1. SMA } 2 \text { Lubuk Basung. } \\
\text { 2. SMA I Tanjung Raya }\end{array}$ & 151 \\
\hline 3 & $\begin{array}{l}\text { Kabupaten Tanah } \\
\text { Datar }\end{array}$ & 15 & 2 & $\begin{array}{l}\text { 1. SMA } 1 \text { Tanah Datar } \\
\text { 2. SMA Salimpaung }\end{array}$ & 133 \\
\hline & Jumlah & 39 & 6 & & 399 \\
\hline
\end{tabular}

Alat pengumpul pada penelitian ini adalah berupa kuesioner untuk peserta didik serta in-depth interview untuk para guru SMA Negeri. Sementara teknik analisa data pada penelitian tahun pertama ini mengunakan rumus persentase dan tahun keduanya menggunakan rumus perbedaan mean ( $t$ - test) serta secara naratif.

\section{HASIL PENELITIAN}

Setelah melalaui langkah-langkah yang telah ditetapkan, maka data yang telah diolah tersebut dapat ditafsirkan dengan melihat persentase yang telah ditetapkan untuk masing-masing indikator. Hasil perhitungannya dapat dilihat pada tabel di bawah ini.

\section{Bentuk Kedisiplinan Peserta Didik SMA Negeri Sumatera Barat Dilihat dari Aspeknya}

Bentuk disiplin peserta didik SMA Negeri Sumatera Barat dapat dipahami dari tabel berikut ini:

Tabel 2: Distribusi Frekuensi Bentuk Kedisiplinan Peserta Didik SMA Negeri Sumatera Barat Dilihat Dari Aspeknya

\begin{tabular}{ccccccc}
\hline \multirow{2}{*}{ Kriteria } & & Baik & Cukup Baik & $\begin{array}{c}\text { Kurang } \\
\text { Baik }\end{array}$ & Tidak baik & Total \\
\hline \multirow{2}{*}{ Ketaatan } & $\mathrm{F}$ & 356 & 43 & 0 & 0 & 399 \\
\cline { 2 - 8 } & $\%$ & 89,22 & 10,78 & 0 & 0 & 100 \\
\hline \multirow{2}{*}{ Sikap Malu } & $\mathrm{F}$ & 246 & 59 & 94 & 0 & 399 \\
\cline { 2 - 8 } & $\%$ & 61,65 & 14,79 & 23,56 & 0 & 100 \\
\hline \multirow{2}{*}{ Loyal } & $\mathrm{F}$ & 138 & 257 & 4 & 0 & 399 \\
\cline { 2 - 8 } & $\%$ & 34,59 & 64,41 & 1,00 & 0 & 100 \\
\hline Cinta & $\mathrm{F}$ & 268 & 131 & 0 & 0 & 399 \\
\cline { 2 - 8 } Keteraturan & $\%$ & 67,17 & 32,83 & 0 & 0 & 100 \\
\hline \multirow{2}{*}{ Membedakan } & $\mathrm{F}$ & 308 & 91 & 0 & 0 & 399 \\
\cline { 2 - 8 } & $\%$ & 77,19 & 22,81 & 0 & 0 & 100 \\
\hline Mengendalikan & $\mathrm{F}$ & 143 & 256 & 0 & 0 & 399 \\
\cline { 2 - 7 } Diri & $\%$ & 35,84 & 64,16 & 0 & 0 & 100 \\
\hline \multirow{2}{*}{ Standar Perilaku } & $\mathrm{F}$ & 350 & 49 & 0 & 0 & 399 \\
\cline { 2 - 7 } & $\%$ & 87,72 & 12,28 & 0 & 0 & 100 \\
\hline
\end{tabular}


Tabel di atas menjelaskan bahwa bentuk kedisiplinan peserta didik SMA Negeri Sumatera Barat pada aspek ketaatan dan kepatuhan dari 399 responden sebanyak $89.2 \%$ responden berada pada kategori baik, sikap malu berbuat menyimpang $61.65 \%$ pada kategori baik, loyal pada norma dan aturan sebanyak $64.41 \%$ berada pada kategori cukup baik dan cinta keteraturan sebanyak $67.17 \%$ responden berada pada kategori baik. Sementara untuk aspek bisa membeda- kan mana yang boleh dan mana yang tidak boleh, sebanyak $77.19 \%$ responden berada pada kategori baik, kemampuan mengendalikan diri sebanyak $64.16 \%$ responden berada pada kategori cukup baik dan untuk aspek tahu standar perilaku yang baik berada pada kategori baik sebanyak $87.72 \%$ dan $12.28 \%$ responden berada pada kategori cukup baik. Untuk lebih jelasnya dapat dilihat visualisasinya pada gambar di bawah ini:

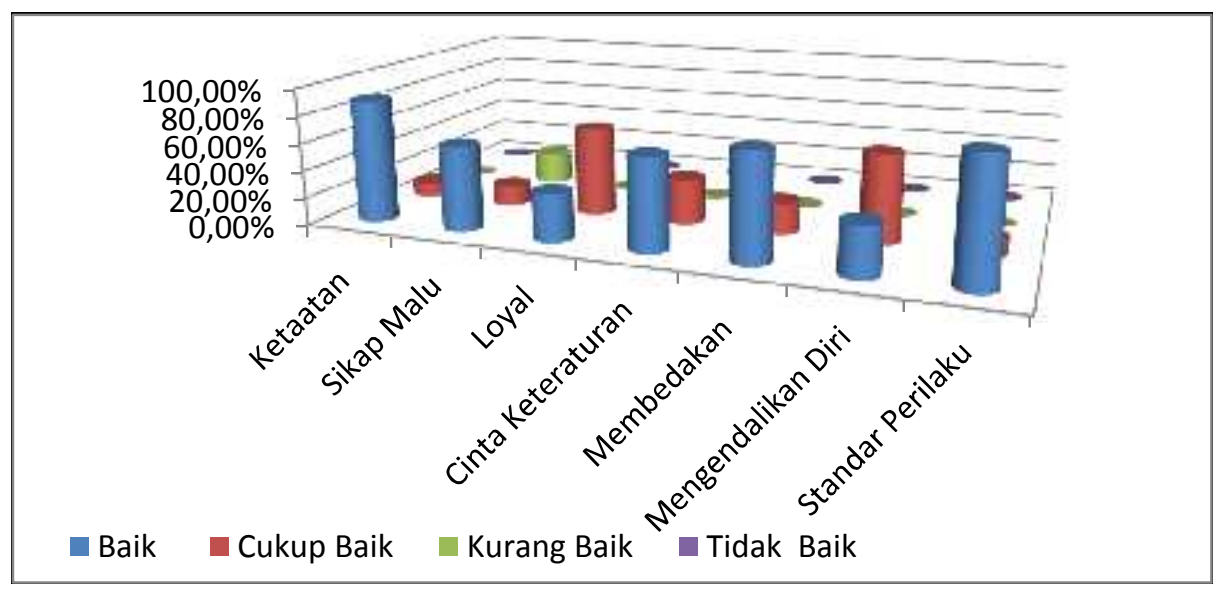

Gambar 1: Bentuk Kedisiplinan Peserta Didik SMA Negeri Sumatera Barat Dilihat dari Aspeknya

\section{Faktor yang Mempengaruhi} Kedisiplinan Peserta didik

Dari hasil pengolahan data yang dilakukan, ditemukan bahwa faktor yang mempengaruhi kedisiplinan peserta didik dapat dilihat sebagaimana tertera pada tabel di bawah ini:

Tabel 3: Distribusi Frekuensi Faktor yang Mempengaruhi Kedisiplinan Peserta Didik di Kabupaten/ Kota Sumatera Barat

\begin{tabular}{lcccccc}
\hline \multicolumn{1}{c}{ Kriteria } & \multicolumn{2}{c}{ PYK } & \multicolumn{2}{c}{ AGAM } & \multicolumn{2}{c}{ TDR } \\
\hline & F & $\%$ & F & $\%$ & F & $\%$ \\
\hline Banyak & 98 & 85.22 & 104 & 78.2 & 129 & 85.43 \\
\hline Cukup & 16 & 13.91 & 29 & 21.8 & 22 & 14.57 \\
\hline Sedikit & 1 & 0.87 & 0 & 0 & 0 & 0 \\
\hline Tidak Ada & 0 & 0 & 0 & 0 & 0 & 0 \\
\hline Total & 115 & 100 & 133 & 100 & 151 & 100 \\
\hline
\end{tabular}

Tabel di atas memperlihatkan bawa faktor yang mempengaruhi kedisiplinan peserta didik di Sumatera Barat adalah sebagai berikut: Untuk Kota Payakumbuh diperoleh hasilnya
85.22\% ini berada pada kategori banyak, untuk Kabupaten Agam 78.2\% berada pada kategori banyak, sementara untuk Kabupaten Tanah Datar $85.43 \%$ berada pada kategori banyak. Hal ini meng- 
gambarkan bahwa di masing-masing Kabupaten/ Kota ditemukan bahwa kedisiplinan peserta didik banyak di- pengaruhi oleh berbagai faktor. Hasil penelitian ini terlihat pada visualisasi gambar di bawah ini:

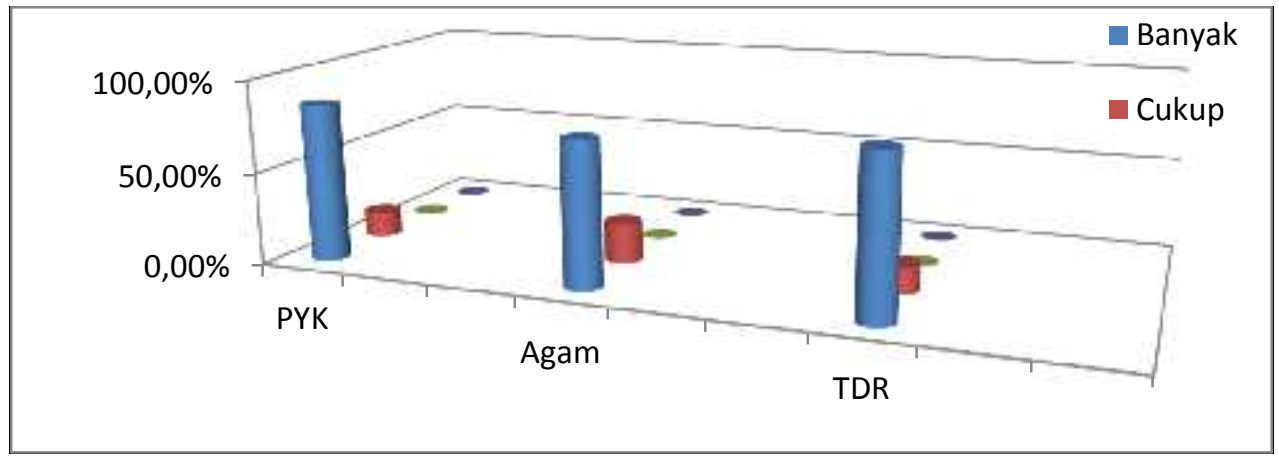

Gambar 2: Faktor yang Mempengaruhi Kedisiplinan Peserta Didik di Kabupaten/ Kota Sumatera Barat

\section{Pembinaan Kedisiplinan Peserta Didik}

Untuk melihat bentuk pembinaan kedisiplinan yang sudah dilakukan oleh guru di SMA N Sumatera Barat di
Kabupaten/Kota yang tersebar di beberapa daerah Kabupaten/Kota di Sumatera Barat, dapat dilihat pada tabel 4 di bawah ini.

Tabel 4: Bentuk Pembinaan Disiplin Yang Dilakukan Guru

\begin{tabular}{|c|c|c|c|c|c|c|}
\hline Kriteria & & Baik & Cukup Baik & Kurang Baik & Tidak baik & Total \\
\hline \multirow{2}{*}{$\begin{array}{l}\text { Mengidentifikasi } \\
\text { Perilaku }\end{array}$} & $\mathrm{F}$ & 122 & 236 & 41 & 0 & 399 \\
\hline & $\%$ & 30,58 & 59,15 & 10,28 & 0 & 100 \\
\hline \multirow{2}{*}{ Mengajarkan } & $\mathrm{F}$ & 192 & 201 & 6 & 0 & 399 \\
\hline & $\%$ & 48,12 & 50,38 & 1,50 & 0 & 100 \\
\hline \multirow{2}{*}{ Keteladanan } & $\mathrm{F}$ & 242 & 152 & 5 & 0 & 399 \\
\hline & $\%$ & 60,65 & 38,10 & 1,25 & 0 & 100 \\
\hline \multirow{2}{*}{ Disiplin Asertif } & $\mathrm{F}$ & 105 & 276 & 18 & 0 & 399 \\
\hline & $\%$ & 26,32 & 69,17 & 4,51 & 0 & 100 \\
\hline \multirow{2}{*}{$\begin{array}{l}\text { Modifikasi Tingkah } \\
\text { Laku }\end{array}$} & $\mathrm{F}$ & 241 & 155 & 3 & 0 & 399 \\
\hline & $\%$ & 60,40 & 38,85 & 0,75 & 0 & 100 \\
\hline \multirow{2}{*}{ Konsekuensi } & $\mathrm{F}$ & 34 & 349 & 16 & 0 & 399 \\
\hline & $\%$ & 8,52 & 87,47 & 4,01 & 0 & 100 \\
\hline \multirow{2}{*}{$\begin{array}{l}\text { Pengendalian dan } \\
\text { Pemasa Bodohan }\end{array}$} & $\mathrm{F}$ & 274 & 117 & 8 & 0 & 399 \\
\hline & $\%$ & 68,67 & 29,32 & 2,01 & 0 & 100 \\
\hline \multirow{2}{*}{$\begin{array}{l}\text { Penguasaan atau } \\
\text { Penekanan }\end{array}$} & $\mathrm{F}$ & 129 & 254 & 16 & 0 & 399 \\
\hline & $\%$ & 32,33 & 63,66 & 4,01 & 0 & 100 \\
\hline \multirow{2}{*}{$\begin{array}{l}\text { Memberikan Hukuman } \\
\text { dan Ancaman }\end{array}$} & $\mathrm{F}$ & 58 & 264 & 77 & 0 & 399 \\
\hline & $\%$ & 14,54 & 66,17 & 19,30 & 0 & 100 \\
\hline \multirow{2}{*}{$\begin{array}{l}\text { Memberikan Tindakan } \\
\text { Tegas yang Mendidik }\end{array}$} & $\mathrm{F}$ & 185 & 203 & 11 & 0 & 399 \\
\hline & $\%$ & 46,37 & 50,88 & 2,76 & 0 & 100 \\
\hline
\end{tabular}


Tabel di atas mengambarkan bahwa bentuk pembinaan kedisiplinan peserta didik di SMA Negeri Sumatera Barat, dari 399 responden untuk aspek mengidentifikasi perilaku yang mendapat kesulitan untuk menerima atau mengikuti aturan, sebanyak $59.15 \%$ responden berada pada kategori cukup baik, aspek mengajarkan sebanyak 50.38\% berada pada kategori cukup baik, aspek keteladanan $60.7 \%$ responden berada pada kategori baik $38.1 \%$ dan disiplin asertif paling banyak berada pada kategori cukup baik yaitu sebanyak $69.2 \%$ responden. Sementaraa untuk aspek modifikasi tingkah laku sebanyak $60.40 \%$ responden berada pada kategori baik, untuk aspek konsekuensi $87.47 \%$ responden berada pada kategori cukup baik, aspek pengendalian diri sebanyak $68.67 \%$ responden berada pada kategori baik dan, aspek penguasaan atau penekanan sebanyak 32,33 berada pada kategori baik, untuk aspek memberikan hukuman dan ancaman paling banyak berada pada kategori cukup baik yaitu dengan persentase sebanyak $66.17 \%$ responden dan terakhir untuk aspek memberikan tindakan tegas yang mendidik paling banyak berada pada kategori cukup baik yaitu sebanyak 50/88\% responden. Untuk lebih jelasnya dapat dilihat visualisasinya pada gambar di bawah ini:

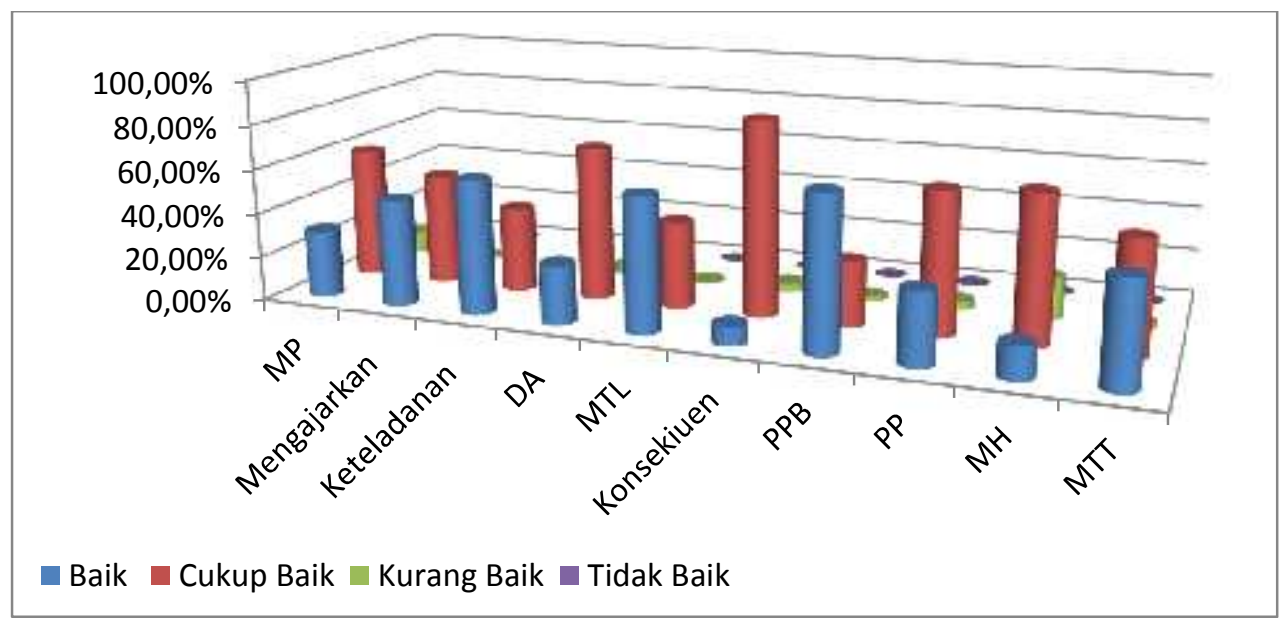

Gambar 3: Bentuk Pembinaan Disiplin yang Dilakukan Guru

\section{PENUTUP}

\section{Kesimpulan}

Dari hasil penelitian tentang pengembangan model pembinaan disiplin peserta didik dalam membangun karakter bangsa berbasis kelas di SMA Negeri Sumatera Barat dapat disimpulkan hal sebagai berikut:

1. Gambaran bentuk dan tingkat kedisiplinan peserta didik di SMA Negeri Sumatera Barat secara umum terkategori baik. Sementara dilihat dari Kabupaten/Kota, gambaran kedisiplinan peserta didik juga ter- kategori baik dan cukup baik begitu pula dari aspek kedisiplinan juga ada yang terkategori baik dan cukup baik.

2. Faktor yang mempengaruhi kedisiplinan peserta didik terkategori banyak dan cukup banyak baik dilihat dari Kabupaten/Kota maupun dilihat dari aspek yang mempengaruhi disiplin itu sendiri.

3. Pembinaan kedisiplinan peserta didik oleh para guru juga terkategori baik dan cukup baik. Ini terlihat dari Kabupaten/Kota dan dari aspek bentuk pembinaan yang dilakukan para guru di SMA Negeri Sumatera Barat. 


\section{Saran}

Berdasarkan hasil penelitian ini maka peneliti mengajukan saran sebagai berikut:

1. Guru hendaknya dapat menambah wawasan, pengetahuan, keterampilan, nilai dan sikap (WPKNS) terkait dengan kedisiplinan peserta didik serta dapat menjadi teladan dalam penegakan disiplin peserta didik.

2. Peserta didik hendaknya dapat mengembangkan disiplin diri dan disiplin terhadap aturan, karena disiplin

\section{DAFTAR RUJUKAN}

Aa Gym. 2006. Saya Tidak Ingin Kaya Tapi Harus Kaya. Bandung: Khas MQ.

Ahmad Rohani. 1995. Pengelolaan Pengajaran.Jakarta: Rineka Cipta.

Arni Muhammad, dkk. 1999. Perbaikan Iklim Kelas yang Kurang Demokratis Di Sekolah Dasar " $X$ " Padang Utara. Forum Pendidikan 24: 19-29.

Darmansyah. 2001. Persepsi Siswa tentang Sisipan Humor dalam Penyampaian Pesan dan Disiplin Belajar Hubungannya dengan Hasil Belajar (Suatu Studi di SMK Negeri 9 Padang). Jurnal Pendidikan SKOLAR; PPS UNP. 3: $136-152$

Doni Koesoema. 2007. Pendidikan Karakter Strategi Mendidik Anak di Zaman Global. Jakarta: Grasindo.

Dorland's Pocket. 1988. Philadelpia: W.B. Saunder Company.

Elfindri, dkk. (2010). Soft Skill. Padang: Baduose Media diri dan disiplin terhadap aturan merupakan kunci kesuksesan.

3. Masyarakat hendaknya dapat memberikan contoh dengan menegakkan disiplin diri, karena anak/peserta didik akan mau disiplin kalau melihat bagaimana orang di sekitarnya juga disiplin.

4. Bagi pihak pemerintah khususnya Dinas Pendidikan baik tingkat Provinsi maupun di Kabupaten/Kota untuk memberikan contoh disiplin diri dan disiplin terhadap aturan sehingga bisa diwarisi oleh para guru dan peserta didik.

Elizabeth B. Hurlock. 1994. Developmental Psychology. New York. MC. Graw Hill.

Entang T. Raka Joni 1995. Pengelolaan Kelas. Jakarta. Rineka Cipta.

Fitria Kasih. 2005. Pembinaan Disiplin Kelas oleh Guru-guru Guna Menciptakan dan Memelihara Suasana Belajar Mengajar yang Efektif. Jurnal KOMUNIKA. Komunikasi Sosial, dan Kebudayaan. 7: $88-97$

J.S. Badudu. 1994. Kamus Umum Bahasa Indonesia.Jakarta: Pustaka Sinar Harapan.

Maurice Balson. 1992. Understanding Classroom Behavior. Victoria: The Australian Council for Educational Research.

M. Furqon Hidayatullah. 2009. Guru Sejati Membangun Insan Berkarakter Kuat dan Cerdas. Surakarta: Yuma Pustaka.

Muri Yusuf. 2005. Metodologi Penelitian (Dasar-dasar Penyelidikan Ilmiah). Padang. UNP Press. 
166 Ta'dib, Volume 15, No. 2 (Desember 2012)

Oemar Hamalik. 1998. Mengajar, Asas, Teknik dan Metode. Bandung.

Oteng Sutisna. 1995 Administrasi Pendidikan Dasar Teoritis untuk Praktek Professional. Bandung: Aksara.

Prayitno. 2009. Ilmu Pendidikan Dasar Teori dan Praksis. Padang: UNP Press.

Indeks

disiplin . 1, 158, 159, 160, 161, 165, 166

Guru $164,165,166$

karakter $1,158,159,160,161,166$

kelas $1,158,159,160,161,165$
Soujitno Irmim dan Abdul Rohim. 2004. Membangun Disiplin Diri Melalui Kecerdasan Spritual dan Emosional. Jakarta: Batavia Press.

Thantawy R. 2003. Budaya Belajar Mahasiswa yang Berprestasi Unggul. Jurnal Bimbingan Konseling. 6: 45-57.

Pendidikan............ 1, 158, 160, 166, 167 peserta didik 1, 158, 159, 160, 161, 162, $163,165,166$

sekolah ............... 1, 158, 159, 160, 161 